Subscriber access provided by BUPMC - Bibliothèque Universitaire Pierre et Marie Curie

Note

\title{
Homochiral versus Heterochiral Trifluoromethylated Pseudoproline Containing Dipeptides: A Powerful Tool to Switch the Prolyl-Amide Bond Conformation
}

Grégory Chaume, Julien Simon, Nathalie Lensen, Julien Pytkowicz, Thierry Brigaud, and Emeric Miclet J. Org. Chem., Just Accepted Manuscript • DOI: 10.1021/acs.joc.7b01944 • Publication Date (Web): 15 Nov 2017

Downloaded from http://pubs.acs.org on November 20, 2017

\section{Just Accepted}

"Just Accepted" manuscripts have been peer-reviewed and accepted for publication. They are posted online prior to technical editing, formatting for publication and author proofing. The American Chemical Society provides "Just Accepted" as a free service to the research community to expedite the dissemination of scientific material as soon as possible after acceptance. "Just Accepted" manuscripts appear in full in PDF format accompanied by an HTML abstract. "Just Accepted" manuscripts have been fully peer reviewed, but should not be considered the official version of record. They are accessible to all readers and citable by the Digital Object Identifier (DOI®). "Just Accepted" is an optional service offered to authors. Therefore, the "Just Accepted" Web site may not include all articles that will be published in the journal. After a manuscript is technically edited and formatted, it will be removed from the "Just Accepted" Web site and published as an ASAP article. Note that technical editing may introduce minor changes to the manuscript text and/or graphics which could affect content, and all legal disclaimers and ethical guidelines that apply to the journal pertain. ACS cannot be held responsible for errors or consequences arising from the use of information contained in these "Just Accepted" manuscripts. 
Heterochiral templates have proved to be potent tools to control the peptide backbone conformation. ${ }^{1}$ For instance, D-amino acids have been largely employed in the design of $\beta$-turn like structures. ${ }^{2}$ The common type I and II are readily obtained from homochiral (LL) and heterochiral (LD) Xaa-Yaa moieties, respectively. Their mirror images (types I' and II'), widely used as strong $\beta$ hairpin nucleators, are preferred with residue pairs (DD) and (DL), which display the opposite chirality. ${ }^{3}$ However, these homo- and heterochiral templates usually share a common trans peptide bond geometry. ${ }^{4}$ To constrain the amide bond conformation, numerous alkyl-substituted pyrrolidine rings have been introduced at the Yaa position as proline surrogates (Figure 1). While they have almost no effect at the $\mathrm{C}^{\beta}$ and $\mathrm{C}^{\gamma}$ positions, $\mathrm{C}^{\alpha}$ and $\mathrm{C}^{\delta}$ alkylations lead to a strong preference for the trans and cis isomers, respectively. ${ }^{5}$ Furthermore, comprehensive studies on pseudoproline

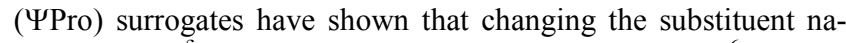
ture at the $\mathrm{C}^{\delta}$ position tuned the cis/trans isomer ratio. ${ }^{6}$ The cis content increasing with the degree of substitution at $\mathrm{C}^{\delta}$, a dimethyl substitution gave almost $100 \%$ of cis isomer. The configuration at the $\mathrm{C}^{\delta}$ position plays also an important role. When the $\mathrm{C}^{\delta}$ substituent and the $\mathrm{C}^{\alpha}$ carbonyl group of a proline ring surrogates

\begin{abstract}
The design of constrained peptides is of prime applications in supramolecular chemistry. Due to its nature, the the cis isomers are much more difficult to stabilize than the trans forms. By using oxazolidine-based pseudoprolines (YPro) substibond can be readily switched from $0 \%$ to $100 \%$ in Xaa- $\Psi$ Pro dipeptides. Our results prove that changing the configuration of
the $\mathrm{C}^{\alpha}$ in Xaa or in $\Psi$ Pro is sufficient to invert the cis:trans populations while changing the nature of the Xaa side chain finely tuned the conformers ratio. Moreover, a strong correlation is
found between the puckering of the oxazolidine ring and the peptide bond conformation. This finding highlights the role of the trifluoromethyl group in the stabilization of the peptide bond
geometry. We anticipate that such templates will be very useful to constrain the backbone geometry of longer peptides.
\end{abstract}

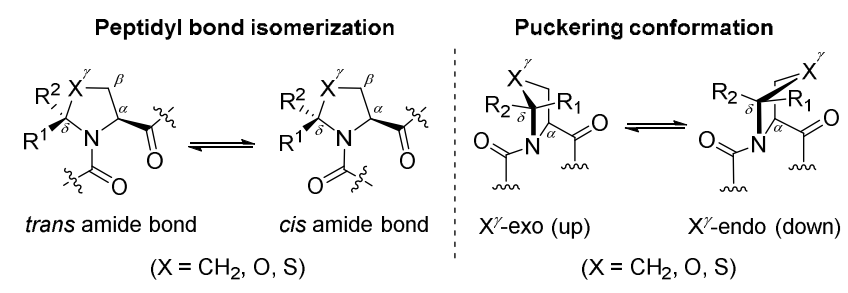

Figure 1. Cis-trans conformers and puckering equilibrium in L-proline $\left(\mathrm{X}=\mathrm{CH}_{2}\right)$ and $\mathrm{L}$-pseudoprolines $\left(\Psi^{\mathrm{R} 1, \mathrm{R} 2} \operatorname{Pro}, \mathrm{X}=\mathrm{O}\right.$, S).

are on the same side $\left(\mathrm{R}^{1}\right.$ position, Figure 1$)$, the trans Xaa-Pro amide bond is favored. Conversely, when they are located on opposite sides ( $\mathrm{R}^{2}$ position, Figure 1$)$, the cis Xaa-Pro amide bond content is enhanced. ${ }^{6,7}$ In $N$-acetyl-thiazolidine tripeptide models, Dumy et al. have shown that the replacement of the $C$-terminal methyl ester with a methyl amide enhanced this behavior. ${ }^{6 \mathrm{~d}}$ In contrast, Lubell et al. have reported that the replacement of the proline with the $(2 S, 5 R)$-5-tert-butylproline ( $\mathrm{R}^{1}$ substituent) into Ac-Xaa-Pro-NHMe dipeptides strongly displaced the cis-trans equilibrium toward the cis conformer, whatever was the nature of the Xaa residue (alkyl, aromatic, hydrogen-bond donors or acceptors). ${ }^{8}$ Overall, these results prove that $\mathrm{C}^{\delta}$-substituted pseudoprolines represent outstanding tools to constrain the peptide bond geometry.

Our group is strongly involved in the synthesis of trifluoromethyl $\left(\mathrm{CF}_{3}\right)$ containing prolines and their pseudoproline surrogates ${ }^{9}$ as well as their incorporation in peptide chains. ${ }^{10}$ In particular, we have reported several studies based on $\mathrm{CF}_{3}$-pseudoprolines ( $\Psi^{\mathrm{CF} 3, \mathrm{H}}$ Pro) model peptides which established the stereoelectronic effects imparted by the $\mathrm{CF}_{3}$ group at the $\mathrm{C}^{\delta}$ position. ${ }^{11}$ As observed in other $\mathrm{C}^{\delta}$-substituted pseudoprolines, we found that the $\mathrm{CF}_{3}$ group led to greater cis peptide bond content when placed at the $\mathrm{R}^{2}$ position (Figure 1). Moreover, the electronic effects of the $\mathrm{CF}_{3}$ group were responsible for a low rotational barrier of the cis-trans peptide bond isomerization as observed in model peptides exhibiting intramolecular hydrogen bond ${ }^{12}$ and for freezing the puckering of the oxazolidine core (Figure 1). ${ }^{11 \mathrm{a}}$ We then focused on a methodological study for the synthesis of Fmoc-XaaSer( $\Psi^{\mathrm{CF} 3, \mathrm{H}}$ Pro)-OMe dipeptides $(\mathrm{Xaa}=\mathrm{Gly}$, L-Ala, L-Val, L-Pro and Aib). ${ }^{10 b}$ NMR conformational studies of these peptides re- 
vealed that the geometry of the amide bond closely depends on the nature of the preceding amino acid Xaa.

In the present paper, we show for the first time that the configuration of the Xaa residue tightly control the cis-trans ratio in ( $\Psi^{\mathrm{CF} 3, \mathrm{H}}$ Pro)-containing dipeptides. For this purpose, a systematic study of twelve homo- and heterochiral Fmoc-XaaSer( $\Psi^{\mathrm{CF} 3, \mathrm{H}}$ Pro)-OMe dipeptides has been conducted (Figure 2). In addition four dipeptides incorporating an achiral Xaa residue have been synthesized and compared to the previous series. Each enantiomer has been analyzed by NMR spectroscopy. Structural features (cis-trans amide bond contents and vicinal coupling constants) are reported allowing us to depict the local role of the $\mathrm{CF}_{3}$ pseudoprolines in the peptide conformation.
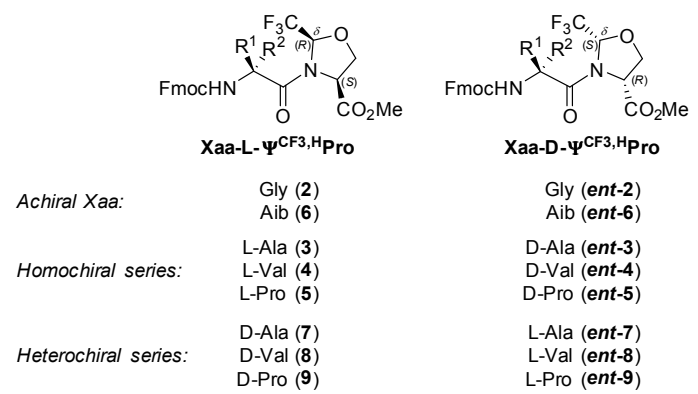

Figure 2. Chemical structure of the Fmoc-XaaSer( $\Psi^{\mathrm{CF3}, \mathrm{H}}$ Pro)-OMe dipeptides.

The dipeptides have been synthesized starting from Fmocprotected L- or D-Xaa amino acid chlorides and L- or D- $\Psi^{\mathrm{CF} 3, \mathrm{H}}$ Pro (1 or ent-1), readily obtained from the condensation between the fluoral hemiacetal and the $(S)$ - or $(R)$-serine methyl ester, respectively. ${ }^{9 \mathrm{~b}}$ The coupling reaction in base-free conditions gave the corresponding dipeptides 2-9 and ent-(2-9) in moderate to good yields as $>95 \%$ enantiopure diastereomers (Table 1$).{ }^{13}$ As previously reported, a dynamic kinetic resolution process (DKR) occurred during the $\mathrm{N}$-amidification leading exclusively to pseudoproline moieties bearing the $\mathrm{CF}_{3}$ group in a cis configuration relative to the methyl ester termination (Figure 2). ${ }^{10 \mathrm{~b}}$ The conformation of the Xaa-YPro peptide bonds has been determined by NMR spectroscopy at $274 \mathrm{~K}$ in $\mathrm{CDCl}_{3}$. Cis and trans conformers were in the slow exchange regime at this temperature. Typical cis/trans exchange cross peaks were observed in the Roesy spectra, whereas dipolar interactions between neighboring protons were associated with negative cross peaks (Figure 3). Cis conformers were characterized by strong $\mathrm{H}^{\alpha}{ }_{\text {Xaa }}-\mathrm{H}^{\alpha}{ }_{\Psi \text { pro }}$ correlations, while trans forms were assigned from $\mathrm{H}^{\alpha}{ }_{\mathrm{Xaa}}-\mathrm{H}^{\delta}{ }_{\Psi \text { pro }}$ cross peaks. ${ }^{14}$ Populations were quantified by the integration of ${ }^{\mathrm{H}} \mathrm{H}$ and ${ }^{19} \mathrm{~F}$ NMR of isolated resonances. When a glycine precedes the L- or D$\Psi^{\mathrm{CF} 3, \mathrm{H}}$ Pro residue the corresponding dipeptide 2 (or ent-2) exhibits a cis conformer content of $61 \%$ (Table 1 ). Thus, in the absence of any side chain at the Xaa position, the peptide backbone already displays a slight preference for the cis conformation. This tendency is significantly enhanced with the Aib residue $(85 \%)$ which bears two methyl groups (Table 1, dipeptides 6 and ent-6). To assess the influence of each methyl group on the peptide bond geometry, we compared the cis content in Xaa-L-YPro and XaaD- $\Psi$ Pro dipeptides with Xaa $=\mathrm{L}$-Ala or D-Ala. In all cases, we observed a marked unbalance between the cis and trans populations. While the cis amide bond was strongly stabilized in heterochiral peptides 7 and $\boldsymbol{e n t} \mathbf{- 7}$ (92\%), the opposite trend was found in homochiral 3 and ent-3 peptides (cis content: 12\%). Note that these population ratio were only slightly displaced in a polar solvent (see supporting information). It is well known that the nature of the amino acid preceding the proline residue is of crucial significance for both the cis-trans ratio ${ }^{4 \mathrm{~b}, \mathrm{c}}$ and

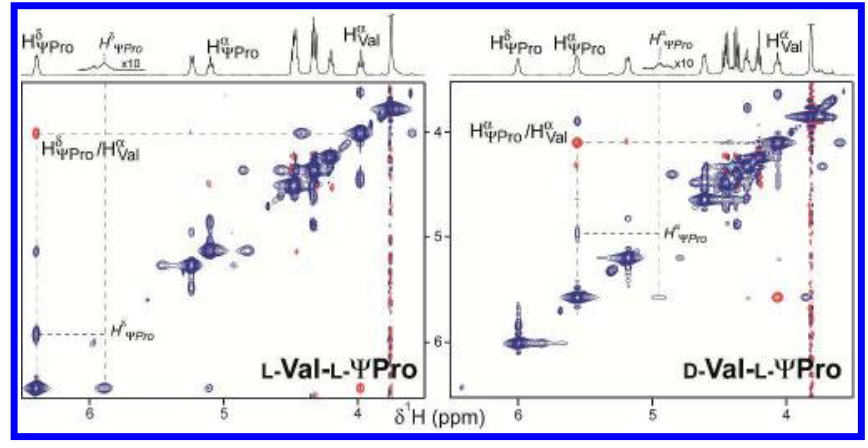

Figure 3. $\mathrm{H}^{\delta}-\mathrm{H}^{\alpha}$ region of the Roesy spectra of Fmoc-L/D-Val$\mathrm{L}-\mathrm{Ser}\left(\Psi^{\mathrm{CF}, \mathrm{H}}\right.$ Pro)-OMe. Spectra have been recorded in $\mathrm{CDCl}_{3}$, at $500 \mathrm{MHz}$ and $274 \mathrm{~K}$. In each spectrum, assignments of the $\mathrm{H}^{\alpha}$ are reported for the two residues together with the YPro $\mathrm{H}^{\delta}$. Assignments of the minor $\Psi$ Pro $\mathrm{H}^{\delta}$ or $\mathrm{H}^{\alpha}$ correspond to the italicized labels $(\sim 5 \%$ in these two examples).

the rate constants of the spontaneous isomerization. ${ }^{15}$ Aromatic residues (Ar) at the Xaa position gives the highest fraction of cis conformer, ${ }^{16}$ probably as a result of Ar-Pro interactions. ${ }^{8 c, 17}$ However, very few examples are available on hetero- and homochiral dipeptides series. Lubell et al. reported that the incorporation of a L-Xaa or a D-Xaa residue at the $N$-terminal position of L-Pro poorly affects the cis-trans ratio in Ac-Xaa-Pro-NHMe dipeptides, the trans conformer always being the major one. ${ }^{8 \mathrm{c}}$ Replacing the proline with a $(2 S, 5 R)$-5-tert-butylproline switches the isomeric equilibrium, both the homochiral and heterochiral dipeptides preferentially adopting a cis peptide conformation. Importantly, we examined a methyl ester dipeptides series so that no hydrogen bond can modulate the cis/trans ratio. Our analyses have shown that homochiral and heterochiral dipeptides have inverted isomer populations but share the same major/minor ratio. These observations highlight the unique behavior of the $\mathrm{CF}_{3^{-}}$ pseudoproline in the Xaa-ЧPro series. As mentioned before, the configuration at the $\mathrm{C}^{\delta}$ is entirely controlled by the L/D stereochemistry of the $\mathrm{CF}_{3}$-pseudoproline (Figure 2). Therefore, this striking observation suggests that the stereospecific interaction between the $\mathrm{CF}_{3}$ group of the $\Psi$ Pro and the methyl substituent of the alanine controls the prolyl amide bond geometry. So, when the $\mathrm{C}^{\delta}$ of the $\Psi$ Pro and the $\mathrm{C}^{\alpha}$ of the Ala residue display the same absolute configuration, the cis amide bond is stabilized.

On the contrary, opposite configurations of these two stereocenters favor the trans amide bond. Moreover, a $85 \%$ cis content is observed for the Aib- $\Psi$ Pro dipeptides which revealed a significant difference of the $\mathrm{CF}_{3} / \mathrm{CH}_{3}$ interactions between the two homotopic methyl groups. In dipeptide 6 , the $(R)-\mathrm{C}^{\delta}-\mathrm{CF}_{3} /$ pro- $R \mathrm{CH}_{3}$ interaction prevails and is responsible for the cis peptide bond geometry preference. In dipeptide ent-6, it is the $(S)-\mathrm{C}^{\delta}-\mathrm{CF}_{3} /$ pro- $S \mathrm{CH}_{3}$ interaction that dominates. Increasing the steric hindrance of the Xaa residue enhanced the cis/trans unbalance. A cis content of $95 \%$ was found in the heterochiral Val-YPro dipeptides 8 and ent8 while only $7 \%$ of the related homochiral compounds (4 and ent4) displayed the cis peptide bond geometry (Table 1 and Figure 3). Finally, when Xaa was a Pro residue, a single conformer was detected in solution, which was assigned to the cis for the heterochiral and to the trans for the homochiral Pro- $\Psi$ Pro dipeptides, respectively (Table 1).

The stereo-electronic effects of the trifluoromethyl group seem crucial in the modulation of the conformational preferences. We have previously reported the ability of the $\mathrm{CF}_{3}$ substituent to efficiently constrain the puckering in 5 -membered rings, the $(2 R)$ $\Psi^{\mathrm{CF} 3, \mathrm{H}}$ Pro being up-puckered and the $(2 S)-\Psi^{\mathrm{H}, \mathrm{CF} 3}$ Pro being 
Table 1. Synthesis, cis/trans populations and vicinal couplings of dipeptides 2-9 and ent-(2-9).

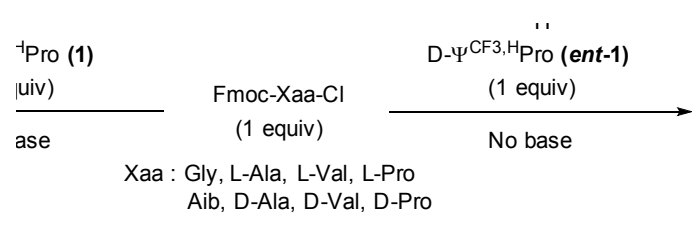

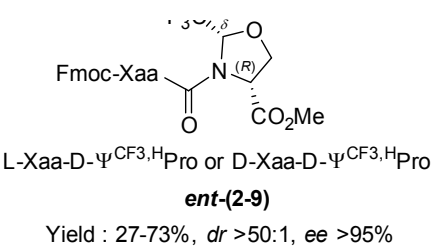

Yield : 27-73\%, $d r>50: 1$, ee $>95 \%$

\begin{tabular}{|c|c|c|c|c|c|c|c|}
\hline \multicolumn{4}{|c|}{ Compound $(\% \text { yield })^{a}$} & \multicolumn{2}{|c|}{ Conformer populations } & \multicolumn{2}{|c|}{ Vicinal couplings ${ }^{b}(\mathrm{~Hz}$} \\
\hline & Xaa-L- $\Psi^{C F, H}$ Pro & & Xaa-D- $\Psi^{C F 3, H}$ Pro & $\% c i s^{c}$ & $\%$ trans $^{c}$ & ${ }^{3} J_{H \alpha-H \beta 2}$ & ${ }^{3} J_{H \alpha-H \beta}$ \\
\hline 2 & Gly-L- $\Psi^{C F 3, H}$ Pro (96) & ent-2 & Gly-D- $\Psi^{C F 3, H}$ Pro $(63)^{d}$ & 61 & 39 & 6.9 & 6.9 \\
\hline 3 & L-Ala-L- $\Psi^{C F 3, H}$ Pro (66) & ent-3 & $D$-Ala-D- $\Psi^{C F 3, H}$ Pro (73) & 12 & 88 & 7.8 & 8.6 \\
\hline 4 & L-Val-L- $\Psi^{C F 3, H} \operatorname{Pro}(59)$ & ent-4 & D-Val-D- $\Psi^{C F, H}$ Pro (53) & 7 & 93 & 7.6 & 9.4 \\
\hline 5 & ${ }_{L-P r o-L-} \Psi^{C F 3, H}$ Pro $(86)$ & ent -5 & $D$-Pro-D- $\Psi^{C F 3, H}$ Pro (53) & 0 & $100^{\circ}$ & 7.5 & 9.2 \\
\hline 6 & Aib-L- $\Psi^{C F 3, H}$ Pro $(55)^{g}$ & ent-6 & Aib-D- $\Psi^{C F 3, H}$ Pro $(63)^{h}$ & 85 & 15 & 4.2 & 7.9 \\
\hline 7 & D-Ala-L- $\Psi^{C F, H}$ Pro (79) & ent-7 & L-Ala-D- $\Psi^{\mathcal{C F}, H} \operatorname{Pro}(56)^{i}$ & 92 & 8 & 4.8 & 8.4 \\
\hline 8 & D-Val-L- $\Psi^{C F 3, H}$ Pro (79) & ent-8 & $L-V a l-D-\Psi^{C F 3, H} \operatorname{Pro}(67)$ & 95 & 5 & 3.6 & 7.9 \\
\hline 9 & D-Pro-L- $\Psi^{C F 3, H}$ Pro & ent-9 & L-Pro-D- $\Psi^{C F 3, H} \operatorname{Pro}(27)^{e}$ & $100^{f}$ & 0 & 4.9 & 8.2 \\
\hline
\end{tabular}

${ }^{\mathrm{a}}$ Yield of the isolated compound. ${ }^{b}$ Measured on $\mathrm{H}^{\alpha}$ resonances and/or on the $\mathrm{CH}_{2}$-TROSY spectra of the major conformer. ${ }^{\mathrm{c}}$ Measured by ${ }^{1} \mathrm{H}$ and ${ }^{19} \mathrm{~F}$ NMR at $274 \mathrm{~K}$ in $\mathrm{CDCl}_{3} .{ }^{\mathrm{d}} 69 \%$ conversion. ${ }^{\mathrm{e}}$ Not optimized reaction. ${ }^{\mathrm{f}}$ Only one conformer is observed for the Xaa-Pro amide bond. ${ }^{\mathrm{g}}$ Three equivalents of Fmoc-Aib-Cl were used. ${ }^{\mathrm{h}}$ Two equivalents of Fmoc-Aib-Cl were used. ${ }^{\mathrm{i}} 65 \%$ conversion. down-puckered in oxazolidine rings. ${ }^{1 \text { la }}$ Statistics performed on Xray structures databases have revealed a significant prevalence of the $\mathrm{C}^{\gamma}$-exo conformation for the trans Xaa-Pro bond, while a $\mathrm{C}^{\gamma}$ endo puckering preference was associated with the cis peptide bond. ${ }^{4 b, 18}$ We thus investigated the correlations between the peptide bond geometry and the ring puckering of the $\Psi$ Pro moieties. ${ }^{19}$ ${ }^{3} J_{\mathrm{H \alpha}-\mathrm{H} \beta 2}$ and ${ }^{3} J_{\mathrm{H} \alpha-\mathrm{H} \beta 3}$ coupling constants were used to determine the ring puckering preferences. These values are extracted from 1D spectra when $\mathrm{H}^{\alpha}$ resonances were well-resolved and/or in a straightforward manner from the $\mathrm{CH}_{2}$-TROSY experiments (Figure 4). ${ }^{20}$ Both vicinal couplings constants should be comparable for $\mathrm{O}^{\gamma}$-exo puckered rings $\left(\mathrm{O}^{\gamma}\right.$ and $\mathrm{C}^{\prime}$ on the same side) with ${ }^{3} J_{\mathrm{H} \alpha-}$ ${ }_{\mathrm{H} \beta 2} \sim^{3} J_{\mathrm{H \alpha}-\mathrm{H} \beta 3} \sim 8 \mathrm{~Hz}$, whereas in $\mathrm{O}^{\gamma}$-endo puckering $\left(\mathrm{O}^{\gamma}\right.$ and $\mathrm{C}^{\prime}$ on the opposite side), typical values are ${ }^{3} J_{\mathrm{H} \alpha-\mathrm{H} \beta 2} \sim 3 \mathrm{~Hz}$ and ${ }^{3} J_{\mathrm{H} \alpha-\mathrm{H} \beta 3}$ $\sim 8 \mathrm{~Hz}^{21}$ Our measurements unambiguously showed that the homochiral dipeptides, which strongly prefer the trans peptide bond, were prone to adopt the $\mathrm{O}^{\gamma}$-exo puckering (Table 1). Conversely, heterochiral dipeptides displayed significantly reduced ${ }^{3} \mathrm{~J}_{\mathrm{H} \alpha-\mathrm{H} \beta 2}$ values. This corresponds to high $\mathrm{O}^{\gamma}$-endo contents that are associated with the cis peptide bonds. The conformational correlations observed in proteins trans $/ \mathrm{C}^{\gamma}$-exo and $c i s / \mathrm{C}^{\gamma}$-endo) were then confirmed in the Xaa-

Figure 4. $\mathrm{C}^{\beta}$ region of the CH2 TROSY spectra of Fmoc-L/DVal-D-Ser $\left(\Psi^{\mathrm{CF} 3, \mathrm{H}}\right.$ Pro)-OMe. Spectra have been recorded in $\mathrm{CDCl}_{3}$, at $500 \mathrm{M} \mathrm{Hz}$ and $274 \mathrm{~K}$. A cross-section through each $\mathrm{H}^{\beta}$ resonance is displayed to show the pure doublets obtained.

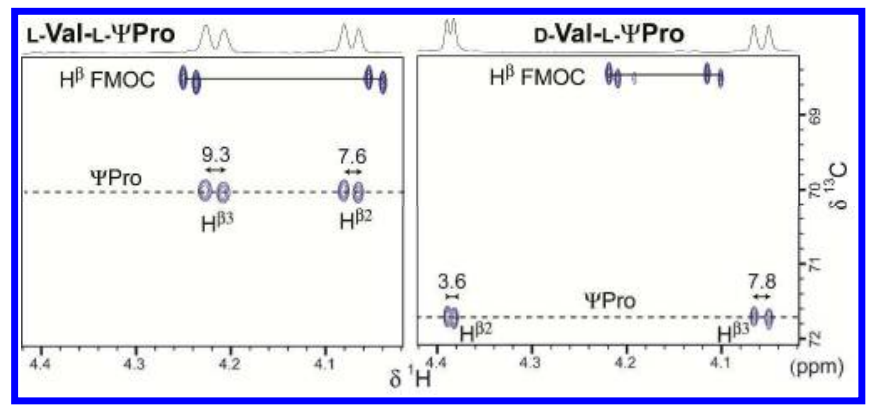

YPro series. Interestingly, when the Xaa was a Gly residue, the absence of any side chain allowed the combination of an $\mathrm{O}^{\gamma}$-exo puckering and a cis peptide bond. The minor trans form of the Gly-L/D- $\Psi^{\mathrm{CF} 3, \mathrm{H}}$ Pro dipeptides was also associated with the $\mathrm{O}^{\gamma}$-exo puckering $\left({ }^{3} J_{\mathrm{H} \alpha-\mathrm{H} \beta 2}=7.5 \mathrm{~Hz}\right.$ and ${ }^{3} J_{\mathrm{H} \alpha-\mathrm{H} \beta 3} \sim 8.5 \mathrm{~Hz}$, see experimental section), which recalls the freezing of the puckering previously observed in the isolated $\Psi^{\mathrm{CF} 3, \mathrm{H}}$ Pro residues. ${ }^{1 \text { a }}$ However, the interactions with the side chain of Xaa govern both the puckering of the oxazolidine and the peptide bond. Changing the Xaa configuration results in the inversion of both the peptide bond and the oxazolidine puckering. In a similar manner, inverting the configuration of the oxazolidine $\mathrm{C}^{\delta}$ which bears the $\mathrm{CF}_{3}$ group restores the puckering and the peptide bond geometry.

In summary, we have shown that the cis-trans ratio of the Xaa$\mathrm{CF}_{3}-\Psi$ Pro amide bond conformation is strongly influenced by the $\Psi$ Pro $\mathrm{C}^{\delta}$ and the Xaa $\mathrm{C}^{\alpha}$ configurations. A strong correlation is observed between the oxazolidine ring puckering and the peptide bond geometry which corresponds to the trends observed in proteins for Xaa-Pro moieties. Since the $\Psi$ Pro $\mathrm{C}^{\delta}$ configuration is governed by the L/D stereochemistry of the $\mathrm{CF}_{3}$-pseudoproline, the backbone geometry is readily tuned by using homochiral or heterochiral Xaa- $\mathrm{CF}_{3}-\Psi$ Pro dipeptides. Cis/trans or trans/cis ratio of 20:1 were obtained in the Val- $\Psi$ Pro series, whereas a single con-

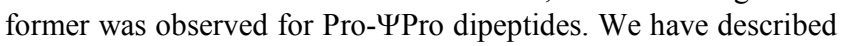
a complete set of 16 dipeptide building blocks that are ready to use for solid-phase peptide synthesis (SPPS). We anticipate that such templates will be very useful to constrain the backbone geometry in longer peptides.

\section{EXPERIMENTAL SECTION}

General Experimental Methods. Unless otherwise mentioned, all the reagents were purchased from commercial source. All glassware was dried in an oven at $150{ }^{\circ} \mathrm{C}$ prior to use. All solvents were purified and dried by standard techniques and distilled prior to use. Dichloromethane was distilled over calcium hydride under argon. All organic extracts were dried over $\mathrm{MgSO}_{4}$, unless otherwise noted. Silica gel (230-400 mesh) was used for 
flash column chromatography, eluting (unless otherwise stated) with cyclohexane/ethyl acetate. Silica TLC plates were visualized under UV light, by a $10 \%$ solution of phosphomolybdic acid in ethanol followed by heating. Infrared spectra (IR) were obtained by Fourier transformation and wavenumbers are given in $\mathrm{cm}^{-1} .{ }^{1} \mathrm{H}$ NMR (400.00 MHz), ${ }^{13} \mathrm{C}$ NMR (100.50 MHz), and ${ }^{19} \mathrm{~F}$ NMR $(376.20 \mathrm{MHz})$ spectra were measured on a JEOL 400 spectrometer. 2D NMR spectra were acquired on a spectrometer operating at a ${ }^{1} \mathrm{H}$ frequency of $500 \mathrm{MHz}$ and equipped with a triple resonance, $\mathrm{z}$-axis pulsed-5 field-gradient cryogenic probehead, optimized for $1 \mathrm{H}$ detection. Complete proton assignments were obtained from the analysis of 2D total correlation spectroscopy (TOCSY) ${ }^{22}$ experiments using $80 \mathrm{~ms}$ DIPSI-2 mixtime, ${ }^{23}$ and $2 \mathrm{D}$ rotating frame Overhauser effect spectroscopy (ROESY) ${ }^{24}$ experiments (typically $250 \mathrm{~ms}$ mixing time). Homonuclear experiments were typically collected as 256 (t1) and 2048 (t2) time-domain matrices over a ${ }^{1} \mathrm{H}$ spectral width of $12 \mathrm{ppm}$, with 8 scans per $\mathrm{t} 1$ increment. Carbon assignment was deduced from heteronuclear $2 \mathrm{D}{ }^{1} \mathrm{H}-{ }^{13} \mathrm{C}$ HSQC experiments, ${ }^{25}$ using $512(\mathrm{t} 1) \times 1024(\mathrm{t} 2)$ time domain matrices, with 16 scans per $\mathrm{t} 1$ increment. $2 \mathrm{D}{ }^{1} \mathrm{H}^{-13} \mathrm{C}^{\mathrm{CH}_{2}}$ TROSY experiments were recorded to extract proton-proton vicinal couplings. ${ }^{20 \mathrm{~b}}$ Data were typically collected as $512(\mathrm{t} 1)$ and 8192 (t2) time-domain matrices over a ${ }^{1} \mathrm{H}$ spectral width of 9 ppm, with 16 scans per t1 increment. Shifted sine-bell window functions were applied in both indirect and direct detected dimensions and extensive zero filling prior to Fourier transformation was used to yield high digital resolution. Spectra were analyzed using the TOPSPIN ${ }^{\mathbb{R}}$ software. Chemical shifts of ${ }^{1} \mathrm{H}$ NMR are expressed in parts per million downfield from $\mathrm{CHCl}_{3}(\delta=7.26)$ in $\mathrm{CDCl}_{3}$. Chemical shifts of ${ }^{13} \mathrm{C} \mathrm{NMR}$ are expressed in parts per million downfield from $\mathrm{CDCl}_{3}$ as internal standard $(\delta=77.0)$. Chemical shifts of ${ }^{19} \mathrm{~F}$ NMR are expressed in parts per million downfield from $\mathrm{C}_{6} \mathrm{~F}_{6}$ as an internal standard $(\delta=-164.9)$. Melting points were uncorrected. High-Resolution Mass Spectra (HRMS) were obtained using ElectroSpray Ionization (ESI) in positive ion mode and a TOF mass analyzer or using Electronic Impact (EI) in positive ion mode by direct insertion probe and double focusing magnetic sector mass analyzer. High Performance Liquid Chromatography (HPLC) was performed on a Daicel Chiralpak IA column $(250 \times 4.6 \mathrm{~mm}, 5 \mu \mathrm{m})$ or Phenomenex Lux Amylose-2 column $(250 \times 4.6 \mathrm{~mm}, 5 \mu \mathrm{m})$. An isocratic program was applied with $n$-Hexane (A) and isopropanol (B) $(\mathrm{v} / \mathrm{v})$ at a flow rate of 1.0 $\mathrm{mL} / \mathrm{min}$. HPLC analyses were performed on an UV detector $(254$ $\mathrm{nm}$ ) or ELSD detector (temperature of the nebulization was set at $30{ }^{\circ} \mathrm{C}$ or $40^{\circ} \mathrm{C}$ ). The injection volume was $10 \mu \mathrm{L}$ for quantitative analysis.

Representative procedure for the preparation of pseudoproline methyl ester. ${ }^{9 b}$ To a solution of Boc-serine methyl ester (1.0 equiv) in toluene at room temperature were added pyridinium p-toluenesulfonate (PPTS) (0.2 equiv) and trifluoroacetaldehyde hydrate (1.2 equiv). The resulting mixture was stirred at room temperature for $1 \mathrm{~h}$, then toluene was added and the reaction mixture was warmed to reflux using a Dean-Stark apparatus. The progress of the reaction was checked by ${ }^{1} \mathrm{H}$ NMR (usually each $5 \mathrm{~h}$ ). After cooling, trifluoroacetaldehyde hydrate ( 0.2 equiv) was added and the reaction mixture rewarming to reflux until the total conversion. The reaction mixture was then cooled to $0{ }^{\circ} \mathrm{C}$ with an ice bath and filtered, and toluene was evaporated. Purification by flash chromatography gave the corresponding pseudoprolines $\mathbf{1}$ or ent-1 as a mixture of two separable diastereomers.

L- $\Psi^{\mathbf{C F 3}, \mathbf{H}}$ Pro-OMe (1). The reaction was performed following the representative procedure starting from Boc-L-serine methyl ester $(21.64 \mathrm{~g}, 98.79 \mathrm{mmol}, 1.0$ equiv) in toluene $(50 \mathrm{~mL})$, PPTS $(4.97$ g, $19.76 \mathrm{mmol}, 0.2$ equiv) and trifluoroacetaldehyde hydrate $(9.8$ $\mathrm{mL}, 118.23 \mathrm{mmol}, 1.2$ equiv). After $1 \mathrm{~h}$ at room temperature, 800
$\mathrm{mL}$ of toluene were added before warming. Purification by flash chromatography $(90: 10$ cyclohexane/ethyl acetate) gave pseudoprolines $(2 S)-1 \mathrm{a}(10.61 \mathrm{~g}, 54 \%)$ as a colorless oil and $(2 R)$ $1 \mathbf{b}(1.87 \mathrm{~g}, 10 \%)$ as a white solid.

(2S)-L- $\Psi^{\text {CF3,H }}$ Pro-OMe (1a): colorless oil; $R f=0.31$ (80:20 cyclohexane/ethyl acetate); $[\alpha]^{23}-50.4\left(c 4.95, \mathrm{CHCl}_{3}\right)$; HRMS (EI) $\mathrm{m} / \mathrm{z}: \mathrm{M}^{+}$Calcd for $\mathrm{C}_{6} \mathrm{H}_{8} \mathrm{~F}_{3} \mathrm{NO}_{3}$ 199.0456; Found 199.0457; HPLC-ELSD (Chiralpak IA, $30{ }^{\circ} \mathrm{C}$ ) $r t=4.30 \mathrm{~min}(60: 40, n$ hexane/isopropanol); see ref. $9 \mathrm{~b}$ for spectral data of $\mathbf{1 a}$.

(2R)-L- $\Psi^{\mathbf{C F 3}, \mathbf{H}}$ Pro-OMe (1b): white solid; $\mathrm{mp} 65-76{ }^{\circ} \mathrm{C} ; R f=0.10$ (80:20 cyclohexane/ethyl acetate); $[\alpha]^{23}{ }_{\mathrm{D}}-17.6$ (c 4.9, $\mathrm{CHCl}_{3}$ ); HRMS (EI) m/z: M Calcd for $\mathrm{C}_{6} \mathrm{H}_{8} \mathrm{~F}_{3} \mathrm{NO}_{3}$ 199.0456; Found 199.0458; HPLC-ELSD (Chiralpak IA, $30{ }^{\circ} \mathrm{C}$ ) $r t=4.49 \mathrm{~min}$ (60:40, $n$-hexane/isopropanol); see ref. $9 \mathrm{~b}$ for spectral data of $\mathbf{1 b}$.

D- $\Psi^{\text {CF3,H}}$ Pro-OMe (ent-1). The reaction was performed following the representative procedure starting from Boc-D-serine methyl ester (16.67 g, $76.10 \mathrm{mmol}, 1.0$ equiv) in toluene (34 mL), PPTS (3.82 g, $15.20 \mathrm{mmol}, 0.2$ equiv) and trifluoroacetaldehyde hydrate (7.6 mL, $91.69 \mathrm{mmol}, 1.2$ equiv). After $1 \mathrm{~h}$ at room temperature, $680 \mathrm{~mL}$ of toluene were added before warming. Purification by flash chromatography (90:10 cyclohexane/ethyl acetate) gave pseudoprolines (2R)-ent-1a $(7.80 \mathrm{~g}, 52 \%)$ as a colorless oil and (2S)-ent-1b (1.31 g, 9\%) as a white solid.

(2R)-D- $\Psi^{\text {CF3,H}}$ Pro-OMe (ent-1a): colorless oil; $R f=0.31$ (80:20 cyclohexane/ethyl acetate); $[\alpha]^{23}+46.4$ (c 4.95, $\left.\mathrm{CHCl}_{3}\right)$; IR (neat) 3338, 2962, 1740, 1439, 1287, 1223, 1158, 1131, $665 \mathrm{~cm}^{-1}$; HPLC-ELSD (Chiralpak IA, $\left.30^{\circ} \mathrm{C}\right) r t=4.05 \mathrm{~min}(60: 40, n-$ hexane/isopropanol); spectral data of ent-1a are similar to those of 1a. $^{9 \mathrm{~b}}$

(2S)-D- $\Psi^{\text {CF3H }}$ Pro-OMe (ent-1b): white solid; mp $65-76{ }^{\circ} \mathrm{C} ; R f=$ 0.10 (80:20 cyclohexane/ethyl acetate); $[\alpha]^{23}{ }_{\mathrm{D}}+19.2$ (c 4.9, $\mathrm{CHCl}_{3}$ ); HRMS (ESI-TOF) m/z: $[\mathrm{M}+\mathrm{Na}]^{+}$Calcd for $\mathrm{C}_{6} \mathrm{H}_{8} \mathrm{~F}_{3} \mathrm{NO}_{3} \mathrm{Na}$ 222.0349; Found 222.0349; HPLC-ELSD (Chiralpak IA, $\left.30{ }^{\circ} \mathrm{C}\right) r t=4.78 \mathrm{~min}(60: 40, n$-hexane/isopropanol); spectral data of ent-1b are similar to those of $\mathbf{1 b} .^{9 \mathrm{~b}}$

Representative procedure for the preparation of Fmoc-aminoacid chloride assisted by ultrasonication. ${ }^{26}$ To a $0.2 \mathrm{M}$ solution of the Fmoc-aminoacid (1.0 equiv) suspended in dichloromethane under argon, was added freshly distilled $\mathrm{SOCl}_{2}$ (13.8 equiv). The mixture was sonicated at romm temperature until the complete disappearence of the precipitate (from $30 \mathrm{~min}$ to $1 \mathrm{~h}$ ), then solvent and excess of $\mathrm{SOCl}_{2}$ were removed in vacuo to give the Fmoc-aminoacid chloride as a white solid directly used without further purification.

Representative procedure for the peptide coupling reaction. $^{10 \mathrm{~b}}$ To a solution of pseudoprolines 1 or ent-1 (1.0 equiv) in dichloromethane was added Fmoc-amino acid chloride (1.1 equiv). The reaction mixture was stirred for $18 \mathrm{~h}$ at room temperature under inert atmosphere, then the solvent was evaporated under reduced pressure. Purification by flash chromatography gave pure dipeptides 2-9 and ent-(2-9) in 27-96\% yield.

Fmoc-Gly-L- $\Psi^{\mathbf{C F 3}, \mathrm{H}}$ Pro-OMe (2). The reaction was performed following the representative procedure starting from a 84:16 diastereomeric mixture of (2S)-1a and (2R)-1b pseudoprolines (7.94 g, $39.90 \mathrm{mmol}, 1.0$ equiv) in dichloromethane $(120 \mathrm{~mL})$ and Fmoc-Gly-Cl (13.83 g, $43.83 \mathrm{mmol}, 1.1$ equiv). Purification by flash chromatography (60:40 cyclohexane/ethyl acetate) gave the pure dipeptide 2 (18.4 g, 96\%) as a 61/39 inseparable mixture of cis/trans rotational isomers in $\mathrm{CDCl}_{3}$ at $274 \mathrm{~K}$ : white solid; $\mathrm{mp}$ $63-83{ }^{\circ} \mathrm{C} ; R_{f}=0.24\left(60: 40\right.$ cyclohexane/ethyl acetate); $[\alpha]^{23}{ }_{\mathrm{D}}-$ 36.0 (c 1.06, $\mathrm{CHCl}_{3}$ ); HRMS (EI) $\mathrm{m} / \mathrm{z}:[\mathrm{M}+\mathrm{Na}]^{+}$Calcd for $\mathrm{C}_{23} \mathrm{H}_{21} \mathrm{~F}_{3} \mathrm{~N}_{2} \mathrm{O}_{6} \mathrm{Na}$ 501.1244; Found 501.1248; HPLC-ELSD (Chi- 
ralpak IA, $\left.40{ }^{\circ} \mathrm{C}\right) r t=6.54 \mathrm{~min}(60: 40, n$-hexane/isopropanol); see ref. $10 \mathrm{~b}$ for spectral data of 2 .

Fmoc-Gly-D- $\Psi^{\text {CF3,H}}$ Pro-OMe (ent-2). The reaction was performed following the representative procedure starting from pseudoproline (2R)-ent-1a (307 mg, $1.54 \mathrm{mmol}, 1.0$ equiv) in dichloromethane $(6 \mathrm{~mL})$ and Fmoc-Gly-Cl $(535 \mathrm{mg}, 1.70 \mathrm{mmol}$, 1.1 equiv). Purification by flash chromatography $(75: 25$ cyclohexane/ethyl acetate) gave recovered pseudoproline $(2 R)$ ent-1a (66 mg, 21\%) and the pure dipeptide ent-2 (462 mg, 63\%) as a $61 / 39$ inseparable mixture of cis/trans rotational isomers in $\mathrm{CDCl}_{3}$ at $274 \mathrm{~K}$ : white solid; $\mathrm{mp} 64-76{ }^{\circ} \mathrm{C} ;[\alpha]^{23}+44.2(c 1.05$, $\mathrm{CHCl}_{3}$ ); HRMS (ESI-TOF) $\mathrm{m} / \mathrm{z}:[\mathrm{M}+\mathrm{Na}]^{+}$Calcd for $\mathrm{C}_{23} \mathrm{H}_{21} \mathrm{~F}_{3} \mathrm{~N}_{2} \mathrm{O}_{6} \mathrm{Na}$ 501.1244; Found 501.1242; HPLC-ELSD (Chiralpak IA, $\left.40^{\circ} \mathrm{C}\right) r t=6.22 \mathrm{~min}(60: 40, n$-hexane/isopropanol); spectral data of ent-2 are similar to those of $2 .^{10 \mathrm{~b}}$

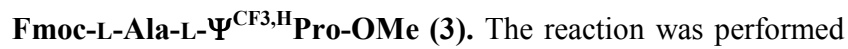
following the representative procedure starting from a $84: 16$ diastereomeric mixture of $(2 S)$-1a and $(2 R)$-1 $\mathbf{b}$ pseudoprolines (1 $\mathrm{g}, 5.03 \mathrm{mmol}, 1.0$ equiv) in dichloromethane $(20 \mathrm{~mL})$ and FmocL-Ala-Cl (1.82 g, $5.50 \mathrm{mmol}, 1.1$ equiv). Purification by flash chromatography (80:20 cyclohexane/ethyl acetate) gave $1.65 \mathrm{~g}$ (66\%) of pure dipeptide 3 as a 12/88 inseparable mixture of cis/trans rotational isomers in $\mathrm{CDCl}_{3}$ at $274 \mathrm{~K}$ : white solid; $\mathrm{mp}$ 65-69 ${ }^{\circ} \mathrm{C} ; R_{f}=0.29$ (70:30 cyclohexane/ethyl acetate); $[\alpha]^{24}{ }_{\mathrm{D}}-$ 81.2 (c 0.95, $\mathrm{CHCl}_{3}$ ); HRMS (ESI-TOF) $\mathrm{m} / \mathrm{z}:[\mathrm{M}+\mathrm{Na}]^{+} \mathrm{Calcd}$ for $\mathrm{C}_{24} \mathrm{H}_{23} \mathrm{~F}_{3} \mathrm{~N}_{2} \mathrm{O}_{6} \mathrm{Na}$ 515.1400; Found 515.1386; HPLC-UV (Lux Amylose-2) $r t=5.31 \mathrm{~min}$ (60:40, $n$-hexane/isopropanol); see Ref. $11 \mathrm{~b}$ for spectral data of $\mathbf{3}$.

Fmoc-D-Ala-L- $\Psi^{\text {CF3,H}}$ Pro-OMe (7). The reaction was performed following the base free representative procedure starting from (2S)-1a pseudoproline (300 $\mathrm{mg}, 1.51 \mathrm{mmol}, 1.0$ equiv) in dichloromethane $(5 \mathrm{~mL})$ and Fmoc-D-Ala-Cl $(547 \mathrm{mg}, 1.66$ mmol, 1.1 equiv). Purification by flash chromatography (70:30 cyclohexane/ethyl acetate) gave the pure dipeptide 7 (545 mg, $79 \%$ ) as a $92 / 8$ inseparable mixture of cis/trans rotational isomers in $\mathrm{CDCl}_{3}$ at $300 \mathrm{~K}$ : white solid; $\mathrm{mp} 87-90{ }^{\circ} \mathrm{C} ; R_{f}=0.40(70: 30$ cyclohexane/ethyl acetate); $[\alpha]^{23}-47.5$ (c 1.0, $\left.\mathrm{CHCl}_{3}\right)$; HRMS (ESI-TOF) m/z: $[\mathrm{M}+\mathrm{Na}]^{+}$Calcd for $\mathrm{C}_{24} \mathrm{H}_{23} \mathrm{~F}_{3} \mathrm{~N}_{2} \mathrm{O}_{6} \mathrm{Na} 515.1400$; Found 515.1400; HPLC-UV (Chiralpak IA) $r t=4.76 \mathrm{~min}$ (60:40, $n$-hexane/isopropanol); see Ref. $11 \mathrm{~b}$ for spectral data of 7 .

Fmoc-L-Ala-D- $\Psi^{\mathbf{C F 3}, \mathrm{H}}$ Pro-OMe (ent-7). The reaction was performed following the representative procedure starting from $(2 R)$ ent-1a pseudoproline (294 mg, $1.48 \mathrm{mmol}, 1.0$ equiv) in dichloromethane $(6 \mathrm{~mL})$ and Fmoc-L-Ala-Cl $(536 \mathrm{mg}, 1.63 \mathrm{mmol}$, 1.1 equiv). Purification by flash chromatography (70:30 cyclohexane/ethyl acetate) gave recovered pseudoproline $(2 R)$ ent-1a (102 mg, 35\%) and the pure dipeptide ent-7 (406 mg, $56 \%$ ) as a $92 / 8$ inseparable mixture of cis/trans rotational isomers in $\mathrm{CDCl}_{3}$ at $305 \mathrm{~K}$ : white solid; $\mathrm{mp} 87-90{ }^{\circ} \mathrm{C}$; $[\alpha]^{23}{ }_{\mathrm{D}}+43.2(c 1.0$, $\mathrm{CHCl}_{3}$ ); HRMS (ESI-TOF) $\mathrm{m} / \mathrm{z}:[\mathrm{M}+\mathrm{Na}]^{+}$Calcd for $\mathrm{C}_{24} \mathrm{H}_{23} \mathrm{~F}_{3} \mathrm{~N}_{2} \mathrm{O}_{6} \mathrm{Na}$ 515.1400; Found 515.1397; HPLC-UV (Chiralpak IA) $r t=4.32 \mathrm{~min}(60: 40, n$-hexane/isopropanol); spectral data of ent-7 are similar to those of $7 .^{11 \mathrm{~b}}$

Fmoc-D-Ala-D- $\Psi^{\mathrm{CF} 3, \mathrm{H}}$ Pro-OMe (ent-3). The reaction was performed following the representative procedure starting from $(2 R)$ ent-1a pseudoproline (300 $\mathrm{mg}, 1.51 \mathrm{mmol}, 1.0$ equiv) in dichloromethane $(5 \mathrm{~mL})$ and Fmoc-D-Ala-Cl (547 mg, 1.66 mmol, 1.1 equiv). Purification by flash chromatography $(70: 30$ cyclohexane/ethyl acetate) gave the pure dipeptide ent-3 $(541 \mathrm{mg}$, $73 \%$ ) as a $12 / 88$ inseparable mixture of cis/trans rotational isomers in $\mathrm{CDCl}_{3}$ at $274 \mathrm{~K}$ : white solid; mp $54-67{ }^{\circ} \mathrm{C}$; $[\alpha]^{23}{ }_{\mathrm{D}}$ $+80.3\left(c\right.$ 1.0, $\left.\mathrm{CHCl}_{3}\right)$; HRMS (ESI-TOF) $\mathrm{m} / \mathrm{z}$ : $[\mathrm{M}+\mathrm{Na}]^{+} \mathrm{Calcd}$ for $\mathrm{C}_{24} \mathrm{H}_{23} \mathrm{~F}_{3} \mathrm{~N}_{2} \mathrm{O}_{6} \mathrm{Na}$ 515.1400; Found 515.1387; HPLC-UV (Lux Amylose-2) $r t=7.48 \mathrm{~min}$ (60:40, $n$-hexane/isopropanol); spectral data of ent-3 are similar to those of 3 . $^{11 \mathrm{~b}}$
Fmoc-L-Val-L- $\Psi^{\text {CF3,H }}$ Pro-OMe (4). The reaction was performed starting from a 84:16 diastereomeric mixture of $(2 S)$-1a and $(2 R)$ $1 \mathrm{~b}$ pseudoprolines $(2.00 \mathrm{~g}, \quad 10.0 \mathrm{mmol}, 1.0$ equiv $)$ in dichloromethane $(30 \mathrm{~mL})$ and Fmoc-L-Val-Cl (3.95 g, $11.0 \mathrm{mmol}$, 1.1 equiv). Purification by flash chromatography (80:20 cyclohexane/ethyl acetate) gave the pure dipeptide 4 (3.09 g, $59 \%$ ) as a $7 / 93$ inseparable mixture of cis/trans rotational isomers in $\mathrm{CDCl}_{3}$ at $300 \mathrm{~K}$ : white solid; $\mathrm{mp} 115-117{ }^{\circ} \mathrm{C} ; R_{f}=0.42(70: 30$ cyclohexane/ethyl acetate); $[\alpha]^{25}-74.5$ (c 1.0, $\left.\mathrm{CHCl}_{3}\right)$; HRMS (ESI-TOF) m/z: $[\mathrm{M}+\mathrm{Na}]^{+}$Calcd for $\mathrm{C}_{26} \mathrm{H}_{27} \mathrm{~F}_{3} \mathrm{~N}_{2} \mathrm{O}_{6} \mathrm{Na}$ 543.1713; Found 543.1698; HPLC-UV (Chiralpak IA) $r t=4.71 \mathrm{~min}(60: 40$, n-hexane/isopropanol); see Ref. $10 \mathrm{~b}$ for spectral data of $\mathbf{4}$.

Fmoc-D-Val-L- $\Psi^{\mathbf{C F 3}, \mathrm{H}}$ Pro-OMe (8). The reaction was performed starting from $(2 S)$-1a pseudoproline $(300 \mathrm{mg}, 1.51 \mathrm{mmol}, 1.0$ equiv) in dichloromethane $(5 \mathrm{~mL})$ and Fmoc-D-Val-Cl $(594 \mathrm{mg}$, $1.66 \mathrm{mmol}, 1.1$ equiv). Purification by flash chromatography (80:20 cyclohexane/ethyl acetate) gave the pure dipeptide 8 (620 $\mathrm{mg}, 79 \%)$ as a $95 / 5$ inseparable mixture of cis/trans rotational isomers in $\mathrm{CDCl}_{3}$ at $305 \mathrm{~K}$ : white solid; $\mathrm{mp} 58-62{ }^{\circ} \mathrm{C} ; R_{f}=0.61$ (70:30 cyclohexane/ethyl acetate); $[\alpha]^{25}-29.9\left(c 1.0, \mathrm{CHCl}_{3}\right)$; IR (neat) $3321,2968,1681 \mathrm{~cm}^{-1}$; ${ }^{1} \mathrm{H}$ NMR $\left(500 \mathrm{MHz}, \mathrm{CDCl}_{3}, 305\right.$ $\mathrm{K}):($ cis rotamer $) \delta 1.03\left(\mathrm{~d}, J=6.9 \mathrm{~Hz}, 6 \mathrm{H}, \mathrm{H}_{\gamma} \mathrm{Val}-\mathrm{H}\right), 2.12(\mathrm{~m}, 1$ $\mathrm{H}, \mathrm{H}_{\beta}$ Val-H), $3.82(\mathrm{~s}, 3 \mathrm{H}, \mathrm{OMe}), 4.05(\mathrm{t}, J=8.7 \mathrm{~Hz}, 1 \mathrm{H}$, $\mathrm{H}_{\alpha}$ Val-H), 4.20 (t, $\left.J=6.9 \mathrm{~Hz}, 1 \mathrm{H}, \mathrm{Fmoc} \mathrm{CH}\right), 4.29$ (t, $J=8.2$ $\mathrm{Hz}, 1 \mathrm{H}, \mathrm{H}_{\beta 3} \Psi$ pro-H), 4.35 (dd, $J=10.5,7.3 \mathrm{~Hz}, 1 \mathrm{H}, \mathrm{Fmoc} \mathrm{CH}_{2}-$ $\mathrm{Ha}), 4.45$ (dd, $\left.J=10.5,6.1 \mathrm{~Hz}, 1 \mathrm{H}, \mathrm{Fmoc} \mathrm{CH}_{2}-\mathrm{Hb}\right), 4.60$ (dd, $J=$ 8.5, 3.4 Hz, $1 \mathrm{H}, \mathrm{H}_{\beta 2} \Psi$ pro-H), 5.22 (d, $\left.J=8.2 \mathrm{~Hz}, 1 \mathrm{H}, \mathrm{NH} \mathrm{Val}\right)$, 5.57 (dd, $J=7.3,3.2 \mathrm{~Hz}, 1 \mathrm{H}, \mathrm{H}_{\alpha} \Psi$ pro-H), 6.00 (q, $J=5.0 \mathrm{~Hz}, 1$ $\mathrm{H}, \mathrm{H}_{\delta} \Psi$ pro-H), 7.31 (t, $J=7.3 \mathrm{~Hz}, 2 \mathrm{H}$, Fmoc arom.), 7.41 (t, $J=$ $7.3 \mathrm{~Hz}, 2 \mathrm{H}$, Fmoc arom.), 7.55 (d, $J=7.3 \mathrm{~Hz}, 1 \mathrm{H}$, Fmoc arom.), 7.56 (d, $J=7.3 \mathrm{~Hz}, 1 \mathrm{H}$, Fmoc arom.), 7.78 (d, $J=7.8 \mathrm{~Hz}, 2 \mathrm{H}$, Fmoc arom.); ${ }^{13} \mathrm{C}$ NMR (100,5 $\left.\mathrm{MHz}, \mathrm{CDCl}_{3}, 298 \mathrm{~K}\right):($ cis rotamer) $\delta 18.4\left(\mathrm{CH}_{3}, \mathrm{C}_{\gamma} \mathrm{Val}\right), 19.0\left(\mathrm{CH}_{3}, \mathrm{C}_{\gamma} \mathrm{Val}\right), 31.4\left(\mathrm{CH}, \mathrm{C}_{\beta}\right.$ Val), $47.0(\mathrm{CH}$, Fmoc $\mathrm{CH}), 52.9\left(\mathrm{CH}_{3}, \mathrm{OMe}\right), 58.0\left(\mathrm{CH}, \mathrm{C}_{\alpha}\right.$ Ipro), $58.4\left(\mathrm{CH}, \mathrm{C}_{\alpha} \mathrm{Val}\right), 67.2\left(\mathrm{CH}_{2}, \mathrm{Fmoc} \mathrm{CH}_{2}\right), 70.4\left(\mathrm{CH}_{2}, \mathrm{C}_{\beta}\right.$ Ipro), 83.9 (q, $J=35.5 \mathrm{~Hz}, \mathrm{CH}, \mathrm{C}_{\delta} \Psi$ pro), $120.1(2 \times \mathrm{CH}$, Fmoc arom.), 122.4 (q, $\left.J=285.6 \mathrm{~Hz}, \mathrm{CF}_{3}\right), 124.9(2 \times \mathrm{CH}, \mathrm{Fmoc}$ arom. $), 127.0(2 \times \mathrm{CH}$, Fmoc arom. $), 127.8(2 \times \mathrm{CH}$, Fmoc arom.), 141.3 ( $2 \times \mathrm{C}$, Fmoc arom. $), 143.4$ (C, Fmoc arom.), 143.5 (C, Fmoc arom.), $156.6(\mathrm{C}, \mathrm{C}=\mathrm{O}), 169.1(\mathrm{C}, \mathrm{C}=\mathrm{O}), 173.2(\mathrm{C}$, $\mathrm{C}=\mathrm{O}) ;{ }^{19} \mathrm{~F}$ NMR $\left(376.2 \mathrm{MHz}, \mathrm{CDCl}_{3}, 298 \mathrm{~K}\right):($ cis rotamer $) \delta-$ $82.8\left(\mathrm{~d}, J=4.3 \mathrm{~Hz}\right.$ ); HRMS (ESI-TOF) $\mathrm{m} / \mathrm{z}:[\mathrm{M}+\mathrm{Na}]^{+}$Calcd for $\mathrm{C}_{26} \mathrm{H}_{27} \mathrm{~F}_{3} \mathrm{~N}_{2} \mathrm{O}_{6} \mathrm{Na}$ 543.1713; Found 543.1710; HPLC-UV (Chiralpak IA) $r t=5.63 \mathrm{~min}(60: 40, n$-hexane/isopropanol).

Fmoc-L-Val-D- $\Psi^{\text {CF3,H}}$ Pro-OMe (ent-8). The reaction was performed following the representative procedure starting from $(2 R)$ ent-1a pseudoproline (108 $\mathrm{mg}, 0.54 \mathrm{mmol}, 1.0$ equiv) in dichloromethane $(5 \mathrm{~mL})$ and Fmoc-L-Val-Cl $(213 \mathrm{mg}, 0.60 \mathrm{mmol}$, 1.1 equiv). Purification by flash chromatography (70:30 cyclohexane/ethyl acetate) gave the pure dipeptide ent-8 (188 mg, $67 \%$ ) as a $95 / 5$ inseparable mixture of cis/trans rotational isomers in $\mathrm{CDCl}_{3}$ at $300 \mathrm{~K}$ : white solid; $\mathrm{mp} 58-62{ }^{\circ} \mathrm{C}$; $[\alpha]^{23}{ }_{\mathrm{D}}+30.2(c 1.0$, $\mathrm{CHCl}_{3}$ ); HRMS (ESI-TOF) m/z: $[\mathrm{M}+\mathrm{Na}]^{+}$Calcd for $\mathrm{C}_{26} \mathrm{H}_{27} \mathrm{~F}_{3} \mathrm{~N}_{2} \mathrm{O}_{6} \mathrm{Na}$ 543.1713; Found 515.1710; HPLC-UV (Chiralpak IA) $r t=4.67 \mathrm{~min}$ (60:40, $n$-hexane/isopropanol); spectral data of ent-8 are similar to those of $\mathbf{8}$.

Fmoc-D-Val-D- $\Psi^{\mathrm{CF3}, \mathrm{H}}$ Pro-OMe (ent-4). The reaction was performed following the representative procedure starting from $(2 R)$ ent-1a pseudoproline $(300 \mathrm{mg}, 1.51 \mathrm{mmol}, 1.0$ equiv) in dichloromethane $(5 \mathrm{~mL})$ and Fmoc-D-Val-Cl (594 mg, 1.66 mmol, 1.1 equiv). Purification by flash chromatography (70:30 cyclohexane/ethyl acetate) gave the pure dipeptide ent-4 $(414 \mathrm{mg}$, $53 \%$ ) as a $7 / 93$ inseparable mixture of cis/trans rotational isomers in $\mathrm{CDCl}_{3}$ at $278 \mathrm{~K}$ : white solid; $\mathrm{mp} 114-117{ }^{\circ} \mathrm{C}$; $[\alpha]^{23}{ }_{\mathrm{D}}+83.4(c$ $1.0, \mathrm{CHCl}_{3}$ ); IR (neat) $3318,2968,1678,1519,1151,735 \mathrm{~cm}^{-1}$; 
HRMS (ESI-TOF) m/z: $[\mathrm{M}+\mathrm{Na}]^{+}$Calcd for $\mathrm{C}_{26} \mathrm{H}_{27} \mathrm{~F}_{3} \mathrm{~N}_{2} \mathrm{O}_{6} \mathrm{Na}$ 543.1713; Found 543.1709; HPLC-UV (Chiralpak IA) $r t=5.54$ min (60:40, $n$-hexane/isopropanol); spectral data of ent-4 are similar to those of $4 .^{10 \mathrm{~b}}$

Fmoc-L-Pro-L- $\Psi^{\mathbf{C F 3}, \mathrm{H}}$ Pro-OMe (5). The reaction was performed following the base free representative procedure starting from $(2 R)$-1a pseudoprolines (544 $\mathrm{mg}, 2.73 \mathrm{mmol}, 1.0$ equiv) in dichloromethane $(9 \mathrm{~mL})$ and Fmoc-L-Pro-Cl (1.05 g, $2.96 \mathrm{mmol}$, 1.1 equiv). Purification by flash chromatography (80:20 cyclohexane/ethyl acetate) gave the pure dipeptide 5 (1.22 g, $86 \%$ ) as a trans rotational isomer in $\mathrm{CDCl}_{3}$ at $300 \mathrm{~K}$ : white solid; $\mathrm{mp} 113-116{ }^{\circ} \mathrm{C} ; R_{f}=0.26$ (70:30 cyclohexane/ethyl acetate); $[\alpha]^{21}{ }_{D}-56.1\left(c\right.$ 1.0, $\left.\mathrm{CHCl}_{3}\right)$; Anal. Calcd for $\mathrm{C}_{26} \mathrm{H}_{25} \mathrm{~F}_{3} \mathrm{~N}_{2} \mathrm{O}_{6}: \mathrm{C}$, 60.23; H, 4.86; N, 5.40; Found: C, 60.22; H, 4.84; N, 5.51. HPLC-UV (Chiralpak IA) $r t=8.72 \mathrm{~min}(60: 40, n-$ hexane/isopropanol); see Ref. $10 \mathrm{~b}$ for spectral data of 5 .

Fmoc-D-Pro-L- $\Psi^{\text {CF3,H}}$ Pro-OMe (9). The reaction was performed following the base free representative procedure starting from (2S)-1a pseudoproline (300 $\mathrm{mg}, 1.51 \mathrm{mmol}, 1.0$ equiv) in dichloromethane $(5 \mathrm{~mL})$ and Fmoc-D-Pro-Cl (591 mg, 1.66 mmol, 1.1 equiv). Purification by flash chromatography $(80: 20$ cyclohexane/ethyl acetate) gave the pure dipeptide 9 (722 mg, $92 \%$ ) as a $13 / 87$ inseparable mixture of Fmoc cis/trans rotational isomer in $\mathrm{CDCl}_{3}$ at $274 \mathrm{~K}$ : white solid; $\mathrm{mp} 62-65^{\circ} \mathrm{C} ; R_{f}=0.33$ (70:30 cyclohexane/ethyl acetate); $[\alpha]^{22}{ }_{\mathrm{D}}-78.0\left(c 1.0, \mathrm{CHCl}_{3}\right)$; IR (neat) $2958,1754,1688,1421 \mathrm{~cm}^{-1} ;{ }^{1} \mathrm{H}$ NMR $\left(500 \mathrm{MHz}, \mathrm{CDCl}_{3}\right.$, $274 \mathrm{~K}):\left(\right.$ cis Fmoc rotamer) $\delta 1.81\left(\mathrm{~m}, 1 \mathrm{H}, \mathrm{H}_{\beta}\right.$ Pro-Ha), $2.08(\mathrm{~m}$, $2 \mathrm{H}, \mathrm{H}_{\gamma}$ Pro-H), 2.10 (m, $1 \mathrm{H}, \mathrm{H}_{\beta}$ Pro-Hb), 3.45 (m, $1 \mathrm{H}, \mathrm{H}_{\delta}$ ProHa), 3.65 (m, $1 \mathrm{H}, \mathrm{H}_{\delta}$ Pro-Hb), 3.78 (m, $1 \mathrm{H}, \mathrm{H}_{\beta 3} \Psi$ pro-H), 3.80 (s, $3 \mathrm{H}, \mathrm{OMe}), 4.00\left(\mathrm{~m}, 1 \mathrm{H}, \mathrm{H}_{\alpha}\right.$ Pro-H), 4.23 (m, $\left.1 \mathrm{H}, \mathrm{Fmoc} \mathrm{CH}\right)$,

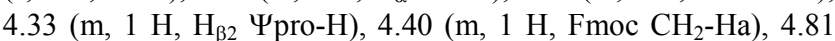
(m, $1 \mathrm{H}$, Fmoc $\left.\mathrm{CH}_{2}-\mathrm{Hb}\right), 5.50$ (dd, $J=7.6,5.3 \mathrm{~Hz}, 1 \mathrm{H}, \mathrm{H}_{\alpha} \Psi$ pro$\mathrm{H}), 5.87\left(\mathrm{q}, J=5.0 \mathrm{~Hz}, 1 \mathrm{H}, \mathrm{H}_{\delta} \Psi\right.$ pro-H), $7.31(\mathrm{t}, J=7.3 \mathrm{~Hz}, 2 \mathrm{H}$, Fmoc arom.), 7.40 (t, $J=7.3 \mathrm{~Hz}, 2 \mathrm{H}$, Fmoc arom.), 7.57 (d, $J=$ $7.3 \mathrm{~Hz}, 1 \mathrm{H}$, Fmoc arom.), 7.60 (d, $J=7.3 \mathrm{~Hz}, 1 \mathrm{H}$, Fmoc arom.), 7.78 (d, $J=7.3 \mathrm{~Hz}, 2 \mathrm{H}, \mathrm{Fmoc}$ arom.); (trans Fmoc rotamer) $\delta$ 1.99 (m, $1 \mathrm{H}, \mathrm{H}_{\beta}$ Pro-Ha), 2.23 (m, $2 \mathrm{H}, \mathrm{H}_{\gamma}$ Pro-H), 2.33 (m, $1 \mathrm{H}$, $\mathrm{H}_{\beta}$ Pro-Hb), 3.60 (m, $1 \mathrm{H}, \mathrm{H}_{\delta}$ Pro-Ha), 3.73 (m, $1 \mathrm{H}, \mathrm{H}_{\delta}$ Pro-Hb), $3.82(\mathrm{~s}, 3 \mathrm{H}, \mathrm{OMe}), 4.25$ (t, $J=6.9 \mathrm{~Hz}, 1 \mathrm{H}, \mathrm{Fmoc} \mathrm{CH}), 4.27$ (dd, $\left.J=10.0,7.3 \mathrm{~Hz}, 1 \mathrm{H}, \mathrm{Fmoc} \mathrm{CH}_{2}-\mathrm{Ha}\right), 4.36(\mathrm{dd}, J=10.0,7.3 \mathrm{~Hz}$, $\left.1 \mathrm{H}, \mathrm{Fmoc} \mathrm{CH}_{2}-\mathrm{Hb}\right), 4.38\left(\mathrm{~m}, 1 \mathrm{H}, \mathrm{H}_{\alpha}\right.$ Pro-H), $4.56\left(\mathrm{~m}, 2 \mathrm{H}, \mathrm{H}_{\beta}\right.$ $\Psi$ pro-H), 5.50 (dd, $J=7.6,5.3 \mathrm{~Hz}, 1 \mathrm{H}, \mathrm{H}_{\alpha} \Psi$ pro-H), 6.03 (q, $J=$ $5.0 \mathrm{~Hz}, 1 \mathrm{H}, \mathrm{H}_{\delta} \Psi$ pro-H), 7.31 (t, $J=7.3 \mathrm{~Hz}, 2 \mathrm{H}$, Fmoc arom.), 7.40 (t, $J=7.3 \mathrm{~Hz}, 2 \mathrm{H}$, Fmoc arom.), 7.56 (d, $J=7.3 \mathrm{~Hz}, 1 \mathrm{H}$, Fmoc arom.), 7.60 (d, $J=7.3 \mathrm{~Hz}, 1 \mathrm{H}$, Fmoc arom.), 7.78 (d, $J=$ $7.3 \mathrm{~Hz}, 2 \mathrm{H}$, Fmoc arom.); ${ }^{13} \mathrm{C}$ NMR $\left(100.5 \mathrm{MHz}, \mathrm{CDCl}_{3}, 300 \mathrm{~K}\right)$ : (cis Fmoc rotamer) $\delta 23.3\left(\mathrm{CH}_{2}, \mathrm{C}_{\beta}\right.$ Pro $), 31.8\left(\mathrm{CH}_{2}, \mathrm{C}_{\gamma}\right.$ Pro), 47.6 $\left(\mathrm{CH}_{2}, \mathrm{C}_{\delta}\right.$ Pro $)$, 47.6 (CH, Fmoc $\left.\mathrm{CH}\right), 53.1\left(\mathrm{CH}_{3}, \mathrm{OMe}\right), 57.3$ (CH, $\mathrm{C}_{\alpha}$ Pro), $57.9\left(\mathrm{CH}, \mathrm{C}_{\alpha} \Psi\right.$ pro $), 66.4\left(\mathrm{CH}_{2}, \mathrm{Fmoc} \mathrm{CH}_{2}\right), 70.4$ $\left(\mathrm{CH}_{2}, \mathrm{C}_{\beta} \Psi\right.$ pro), 84.0 (q, $J=35.5 \mathrm{~Hz}, \mathrm{CH}, \mathrm{C}_{\delta} \Psi$ pro $), 120.0(2 \times$ $\mathrm{CH}$, Fmoc arom.), 122.5 (q, $\left.J=284.7 \mathrm{~Hz}, \mathrm{CF}_{3}\right), 125.0(\mathrm{CH}$, Fmoc arom. $), 125.1$ (CH, Fmoc arom. $), 127.2(2 \times \mathrm{CH}, \mathrm{Fmoc}$ arom. $)$, $127.9(2 \times \mathrm{CH}$, Fmoc arom. $), 141.2(2 \times \mathrm{C}$, Fmoc arom. $), 143.6$ (C, Fmoc arom.), 143.8 (C, Fmoc arom.), 153.6 (C, C=O), 168.8 $(\mathrm{C}, \mathrm{C}=\mathrm{O}), 173.1(\mathrm{C}, \mathrm{C}=\mathrm{O})$; (trans Fmoc rotamer) $\delta 24.8\left(\mathrm{CH}_{2}, \mathrm{C}_{\beta}\right.$ Pro), $30.6\left(\mathrm{CH}_{2}, \mathrm{C}_{\gamma}\right.$ Pro $), 46.9(\mathrm{CH}, \mathrm{Fmoc} \mathrm{CH}), 47.1\left(\mathrm{CH}_{2}, \mathrm{C}_{\delta}\right.$ Pro), $53.0\left(\mathrm{CH}_{3}, \mathrm{OMe}\right), 57.9\left(\mathrm{CH}, \mathrm{C}_{\alpha} \Psi\right.$ pro $), 58.1\left(\mathrm{CH}, \mathrm{C}_{\alpha}\right.$ Pro), $67.7\left(\mathrm{CH}_{2}\right.$, Fmoc $\left.\mathrm{CH}_{2}\right), 70.4\left(\mathrm{CH}_{2}, \mathrm{C}_{\beta} \Psi\right.$ pro), 84.0 (q, $J=35.5$ $\mathrm{Hz}, \mathrm{CH}, \mathrm{C}_{\delta} \Psi$ pro), $120.0(2 \times \mathrm{CH}$, Fmoc arom.), 122.8 (q, $J=$ $\left.286.2 \mathrm{~Hz}, \mathrm{CF}_{3}\right), 125.0$ ( $\mathrm{CH}$, Fmoc arom.), 125.1 ( $\mathrm{CH}$, Fmoc arom. $), 127.0(2 \times \mathrm{CH}$, Fmoc arom. $), 127.7(2 \times \mathrm{CH}, \mathrm{Fmoc}$ arom.), 141.2 ( $2 \times \mathrm{C}$, Fmoc arom. $), 143.6$ (C, Fmoc arom. $), 143.8$ (C, Fmoc arom.), $155.2(\mathrm{C}, \mathrm{C}=\mathrm{O}), 169.5(\mathrm{C}, \mathrm{C}=\mathrm{O}), 173.7(\mathrm{C}$, $\mathrm{C}=\mathrm{O}) ;{ }^{19} \mathrm{~F}$ NMR $\left(376.2 \mathrm{MHz}, \mathrm{CDCl}_{3}, 298 \mathrm{~K}\right.$ ) : (cis Fmoc and trans Fmoc rotamers) $\delta-82.8(\mathrm{~d}, J=5.5 \mathrm{~Hz}$ ); HRMS (ESI-TOF) $\mathrm{m} / \mathrm{z}:[\mathrm{M}+\mathrm{Na}]^{+}$Calcd for $\mathrm{C}_{26} \mathrm{H}_{25} \mathrm{~F}_{3} \mathrm{~N}_{2} \mathrm{O}_{6} \mathrm{Na}$ 541.1557; Found 541.1553; HPLC-UV (Lux Amylose-2) $r t=8.19 \min (60: 40, n$ hexane/isopropanol)

Fmoc-L-Pro-D- $\Psi^{\text {CF3,H}}$ Pro-OMe (ent-9). The reaction was performed following the representative procedure starting from $(2 R)$ ent-1a pseudoproline (123 $\mathrm{mg}, 0.62 \mathrm{mmol}, 1.0$ equiv) in dichloromethane ( $5 \mathrm{~mL}$ ) and Fmoc-L-Pro-Cl (242 mg, $0.68 \mathrm{mmol}$, 1.1 equiv). Purification by flash chromatography (70:30 cyclohexane/ethyl acetate) gave the pure dipeptide ent-9 $(87 \mathrm{mg}$, $27 \%$ ) as a $13 / 87$ inseparable mixture of Fmoc cis/trans rotational isomer in $\mathrm{CDCl}_{3}$ at $274 \mathrm{~K}$ : white solid; $\mathrm{mp} 62-65^{\circ} \mathrm{C} ; R_{f}=0.33$ (70:30 cyclohexane/ethyl acetate); $[\alpha]^{22}+79.2$ (c 1.0, $\mathrm{CHCl}_{3}$ ); HRMS (ESI-TOF) $\mathrm{m} / \mathrm{z}$ : $[\mathrm{M}+\mathrm{Na}]^{+}$Calcd for $\mathrm{C}_{26} \mathrm{H}_{25} \mathrm{~F}_{3} \mathrm{~N}_{2} \mathrm{O}_{6} \mathrm{Na}$ 541.1557; Found 541.1553; HPLC-UV (Lux Amylose-2) $r t=$ $7.40 \mathrm{~min}(60: 40, n$-hexane/isopropanol); spectral data of ent-9 are similar to those of 9.

Fmoc-D-Pro-D- $\Psi^{\text {CF3,H}}$ Pro-OMe (ent-5). The reaction was performed following the representative procedure starting from $(2 R)$ ent-1a pseudoproline $(300 \mathrm{mg}, 1.51 \mathrm{mmol}, 1.0$ equiv $)$ in dichloromethane $(5 \mathrm{~mL})$ and Fmoc-D-Pro-Cl $(591 \mathrm{mg}, 1.66 \mathrm{mmol}$, 1.1 equiv). Purification by flash chromatography (70:30 cyclohexane/ethyl acetate) gave the pure dipeptide ent-5 (414 mg, $53 \%$ ) as a trans rotational isomers in $\mathrm{CDCl}_{3}$ at $300 \mathrm{~K}$ : white solid; mp 113-116 ${ }^{\circ} \mathrm{C}$; $[\alpha]^{21}{ }_{\mathrm{D}}+53.0\left(c 1.0, \mathrm{CHCl}_{3}\right)$; HRMS (ESITOF) $\mathrm{m} / \mathrm{z}:[\mathrm{M}+\mathrm{Na}]^{+}$Calcd for $\mathrm{C}_{26} \mathrm{H}_{25} \mathrm{~F}_{3} \mathrm{~N}_{2} \mathrm{O}_{6} \mathrm{Na}$ 541.1557; Found 541.1554; HPLC-UV (Chiralpak IA) $r t=6.03 \min (60: 40$, $n$-hexane/isopropanol); spectral data of ent-5 are similar to those of $5 .{ }^{10 \mathrm{~b}}$

Fmoc-Aib-L- $\Psi^{\mathrm{CF3}, \mathrm{H}}$ Pro-OMe (6). The reaction was performed following the base free representative procedure starting from a $84: 16$ diastereomeric mixture of $(2 S)-\mathbf{1 a}$ and $(2 R)-\mathbf{1 b}$ pseudoprolines $(500 \mathrm{mg}, 2.51 \mathrm{mmol}, 1.0$ equiv $)$ in dichloromethane $(7.5 \mathrm{~mL})$ and Fmoc-Aib-Cl $(2.59 \mathrm{~g}, 7.74 \mathrm{mmol}$, 3.0 equiv). Purification by flash chromatography $(70: 30$ cyclohexane/ethyl acetate) gave the pure dipeptide 6 (700 mg, $55 \%$ ) as a $85 / 15$ inseparable mixture of cis/trans rotational isomers in $\mathrm{CDCl}_{3}$ at $274 \mathrm{~K}$ : white solid; $\mathrm{mp} 64-79{ }^{\circ} \mathrm{C} ; R_{f}=0.24$ (70:30 cyclohexane/ethyl acetate); $[\alpha]^{22}-35.5$ (c 1.05, $\mathrm{CHCl}_{3}$ ); HRMS (ESI-TOF) m/z: $[\mathrm{M}+\mathrm{Na}]^{+}$Calcd for $\mathrm{C}_{25} \mathrm{H}_{25} \mathrm{~F}_{3} \mathrm{~N}_{2} \mathrm{O}_{6} \mathrm{Na}$ 529.1557; Found 529.1554; HPLC-UV (Chiralpak IA) $r t=6.41$ $\min (80: 20, n$-hexane/isopropanol); see Ref. $10 \mathrm{~b}$ for spectral data of 6.

Fmoc-Aib-D- $\Psi^{\mathrm{CF} 3 \mathrm{H}}$ Pro-OMe (ent-6). The reaction was performed following the representative procedure starting from pseudoproline ( $2 R$ )-ent-1a ( $508 \mathrm{mg}, 2.55 \mathrm{mmol}, 1.0$ equiv) in dichloromethane $(10 \mathrm{~mL})$ and Fmoc-Aib-Cl $(1.75 \mathrm{~g}, 5.1 \mathrm{mmol}$, 2.0 equiv). Purification by flash chromatography (70:60 cyclohexane/ethyl acetate) gave pure dipeptide ent-6 (462 mg, $63 \%$ ) as a $85 / 15$ inseparable mixture of cis/trans rotational isomers in $\mathrm{CDCl}_{3}$ at $274 \mathrm{~K}$ : white solid; $\mathrm{mp} 64-79{ }^{\circ} \mathrm{C} ;[\alpha]^{22} \mathrm{D}$ $+36.5\left(\right.$ c 1.00, $\left.\mathrm{CHCl}_{3}\right)$; HRMS (ESI-TOF) $\mathrm{m} / \mathrm{z}:[\mathrm{M}+\mathrm{Na}]^{+} \mathrm{Calcd}$ for $\mathrm{C}_{25} \mathrm{H}_{25} \mathrm{~F}_{3} \mathrm{~N}_{2} \mathrm{O}_{6} \mathrm{Na}$ 529.1557; Found 529.1554; HPLC-UV (Chiralpak IA) $r t=6.75 \mathrm{~min}(80: 20, n$-hexane/isopropanol); spectral data of ent-6 are similar to those of 6 .

\section{ASSOCIATED CONTENT}

\section{Supporting Information}

1D proton, 1D fluorine, and 1D carbon NMR spectra for the described compounds; 2D Roesy and $\mathrm{CH}_{2}$-Trosy spectra of L-ValL- $\Psi^{\mathrm{CF} 3, \mathrm{H}}$ Pro, D-Val-D- $\Psi^{\mathrm{CF} 3, \mathrm{H}}$ Pro, L-Val-D- $\Psi^{\mathrm{CF} 3, \mathrm{H}}$ Pro and D-Val-L$\Psi^{\mathrm{CF} 3, \mathrm{H}}$ Pro; complete set of ${ }^{3} \mathrm{~J}$ measurements, chiral HPLC chromatograms. This material is available free of charge via the Internet at http://pubs.acs.org. 


\section{AUTHOR INFORMATION}

\section{Corresponding Author}

*E-mail: gregory.chaume@u-cergy.fr, emeric.miclet@upmc.fr

\section{Notes}

The authors declare no competing financial interests.

\section{ACKNOWLEDGMENTS}

G.C. thanks the Agence Nationale de la Recherche for financial support (No. ANR-09-JCJC-0060). Authors thank Gwenaëlle Sizun-Thomé for the HPLC analysis.

\section{REFERENCES}

(1) (a) Ranbhor, R.; Ramakrishnan, V.; Kumar, A.; Durani, S. Biopolymers 2006, 83, 537-545; (b) Durani, S. Acc. Chem. Res. 2008, 41, 13011308 and references therein.

(2) (a) Chalmers, D. K.; Marshall, G. R. J. Am. Chem. Soc. 1995, 117, 5927-5937; (b) Gellman, S. H. Curr. Opin. Chem. Biol. 1998, 2, 717-725; (c) Venkatraman, J.; Shankaramma, S. C.; Balaram, P. Chem. Rev. 2001, 101, 3131-3152; (d) Rotondi, K. S.; Gierasch, L. M. Biopolymers: Peptide Sci. 2006, 84, 13-22; (e) Mahalakshmi, R.; Balaram, P. The Use of DAmino Acids in Peptide Design. In D-Amino Acids: A New Frontier in Amino Acid and Protein Research - Practical Methods and Protocols; Konno, R., Brückner, H., D’Aniello, A., Fischer, G. H., Fujii, N., Homma, H., Eds.; Nova Science Publishers: New York, 2007; pp 415-430.

(3) (a) Sibanda, B. L.; Thornton, J. M. Nature 1985, 316, 170-174; (b) Sibanda, B. L.; Blundell, T. L.; Thornton, J. M. J. Mol. Biol. 1989, 206, 759-757;. (c) Haque, T. S.; Little, J. C.; Gellman, S. H. J. Am. Chem. Soc. 1994, 116, 4105-4106.

(4) (a) Jabs, A.; Weiss, M. S.; Hilgenfeld, R. J. Mol. Biol. 1999, 286, 291-304; (b) Pal, D.; Chakrabarti, P. J. Mol. Biol. 1999, 294, 271-288; (c) Joseph, A. Praveen, Srinivasan, N.; de Brevern, A. G. Amino Acids 2012, 43, 1369-1381 and references therein.

(5) Dugave, C.; Demange, L. Chem. Rev. 2003, 103, 2475-532; (b) Che, Y.; Marshall, G. R. Biopolvmers 2006, 81, 392-406; (c) De Poli, M.; Moretto, A.; Crisma, M.; Peggion, C.; Formaggio, F.; Kaptein, B.; Broxterman, Q. B.; Toniolo, C. Chem. Eur. J. 2009, 15, 8015-8025; Mothes, C.; Caumes, C.; Guez, A.; Boullet, H.; Gendrineau, T.

(6) (a) Dumy, P.; Keller, M.; Ryan, D. E.; Rohwedder, B.; Wöhr, T.; Mutter, M. J. Am. Chem. Soc. 1997, 119, 918-925; (b) Keller, M.; Sager, C.; Dumy, P.; Schutkowski, M.; Fischer, G. S.; Mutter, M. J. Am. Chem. Soc. 1998, 120, 2714-2720; (c) Mutter, M.; Wöhr, T.; Gioria, S.; Keller, M. Biopolvmers: Peptide Sci. 1999, 51, 121-128; (d) Jamet, H.; Jourdan, M.; Dumy, P. J. Phvs. Chem. B 2008, 112, 9975-9981.

(7) Beausoleil, E.; Lubell, W. D. J. Am. Chem. Soc. 1996, 118, 1290212908 .

(8) (a) Halab, L.; Lubell, W. D. J. Org. Chem. 1999, 64, 3312-3321; (b) Halab, L.; Lubell, W. D. J. Peptide Sci. 2001, 7, 92-104; (c) Halab, L.; Lubell, W. D. J. Am. Chem. Soc. 2002, 124, 2474-2484.
(9) (a) Caupène, C.; Chaume, G.; Ricard, L.; Brigaud, T. Org. Lett. 2009, 11, 209-212; (b) Chaume, G.; Barbeau, O.; Lesot, P.; Brigaud, T. J. Org. Chem. 2010, 75, 4135-4145; (c) Lubin, H.; Pytkowicz, J.; Chaume, G.; Sizun-Thomé, G.; Brigaud, T. J. Org. Chem. 2015, 80, 2700-2708;

(10) (a) Chaume, G.; Lensen, N.; Caupène, C.; Brigaud, T. Eur. J. Org. Chem. 2009, 5717-5724; (b) Chaume, G.; Simon, J.; Caupène, C.; Lensen, N.; Miclet, E.; Brigaud, T. J. Org. Chem. 2013, 78, 10144-10153; (c) Simon, J.; Pytkowicz, J.; Lensen, N.; Chaume, G.; Brigaud, T. J. Org. Chem. 2016, 81, 5381-5392.

(11) (a) Feytens, D.; Chaume, G.; Chassaing, G.; Lavielle, S.; Brigaud, T.; Byun, B. J.; Kang, Y. K.; Miclet, E. J. Phvs. Chem. B 2012, 116, 4069-4079; (b) Chaume, G.; Feytens, D.; Chassaing, G.; Lavielle, S.; Brigaud, T.; Miclet, E. New J. Chem. 2013, 37, 1336-1342.

(12) Cox, C.; Lectka, T. J. Am. Chem. Soc. 1998, 120, 10660-10668.

(13) Each enantiomer has been synthetized independently in a stereoselective way. Diastereomeric and enantiomeric purities have been confirmed by analytical chiral HPLC of the enantiomers and their co-mixture (see Experimental Section and Supporting Information). The chromatogram of $\mathbf{2}$ showed a slightly weaker $91 \%$ enantiomeric excess.

(14) For the dipeptides incorporating the Aib residue, $\mathrm{CH}_{3}$ resonances have been used to discriminate cis/trans isomers.

(15) Reimer, U.; Scherer, G.; Drewello, M.; Kruber, S.; Schutkowski, M.; Fischer, G. J. Mol. Biol. 1998, 279, 449-460.

(16) (a) Stewart, D. E.; Sarkar, A.; Wampler, J. E. J. Mol. Biol. 1990, 214, 253-260; (b) Frömmel, C.; Preissner, R. FEBS Lett. 1990, 277, 159163; (c) MacArthur, M. W.; Thornton, J. M. J. Mol. Biol. 1991, 218, 397 412.

(17) Taylor, C. M.; Hardre, R.; Edwards, P. J. B.; Park, J. H. Org. Lett. 2003, 5, 4413-4416.

(18) (a) Milner-White, E. J.; Bell, L. H.; Maccallum, P. H. J. Mol. Biol. 1992, 228, 725-734; (b) Vitagliano, L.; Berisio, R.; Mastrangelo, A.; Mazzarella, L.; Zagari, A. Protein Sci. 2001, 10, 2627-2632.

(19) (a) DeTar, D. F.; Luthra, N. P. J. Am. Chem. Soc. 1977, 99, $1232-$ 1244. (b) Kang, Y. K., Choi, H. Y. Biophvs. Chem. 2004, 111, 135-142. (c) Kang, Y. K. J. Phys. Chem. B 2004, 108, 5463-5465. (d) Kang, Y. K. Park, J. H. J. Phys. Chem. B 2006, 110, 17645-17655. (e) Kang, Y. K. J. Phys. Chem. B 2007, 111, 10550-10556.

(20) (a) Miclet, E.; Williams, D. C.; Clore, G. M.; Bryce, D. L.; Boisbouvier, J.; Bax, A. J. Am. Chem. Soc. 2004, 126, 10560-10570; (b) Guichard, G.; Violette, A.; Chassaing, G.; Miclet, E. Magn. Reson. Chem. 2008, 46, 918-924; (c) Bouillère, F.; Feytens, D.; Gori, D.; Guillot, R.; Kouklovsky, C.; Miclet E.; Alezra, V. Chem. Commun. 2012, 48, 19821984.

(21) (a) Altona, C.; Sundaralingam, M. J. Am. Chem. Soc. 1972, 94, 8205-8212; (b) Schmidt, J. M. J. Magn. Reson. 2007, 186, 34-50.

(22) Dhalluin, C.; Wieruszeski, J. M.; Lippens, G. J. Magn. Reson. 1996, 111, 168-170.

(23) Shaka, A. J.; Lee, C.J.; Pines, A. J. Magn. Reson. 1988, 77, 274293.

(24) Hwang, T.; Shaka, A. J. J. Am. Chem. Soc. 1992, 114, 3157-3159.

(25) Mori, S.; Abeygunawardana, C.; Johnson, M. O.; Vanzijl, P. C. M. J. Magn. Reson. 1995, 108, 94-98.

(26) Patil, K. B. S.; Babu, V. V. S. Lett. Pept. Sci. 2002, 9, 227-229. 


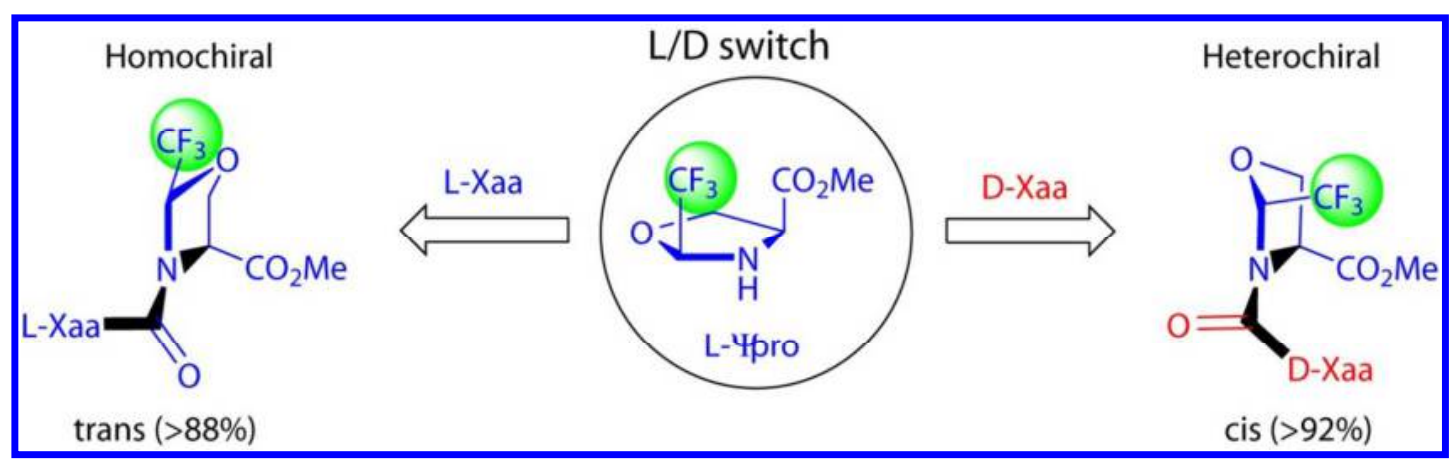

1
2
3
4
5
6
7
8
9
10
11
12
13
14
15
16
17
18
19
20
21
22
23
24
25
26
27
28
29
30
31
32
33
34
35
36
37
38
39
40
41
42
43
44
45
46
47
48
49
50
51
52
53
54
55
56
57
58
60

60 